\section{Addressing post-transplant summer water stress in Pinus pinea and Quercus ilex seedlings}

\author{
Marta Pardos, Rafael Calama, Carolina Mayoral, Guillermo Madrigal, \\ Mariola Sánchez-González
}

In central Spain, post-transplant water stress produces high seedling mortality after the first summer following outplanting. Our study was designed to determine whether survival and performance of outplanted stone pine (Pinus pinea) and holm oak (Quercus ilex) seedlings in a burned area could be improved by summer irrigation and mulching and to identify whether there is a species-specific adaptive capacity to respond to treatment and environment. Seedlings were outplanted in March 2011 in 200 planting holes in an area of 1.1 ha. Mulch was added in June; irrigation started in July and was repeated every week until mid-September. The severity of the 2011 summer drought constrained growth rates and photosynthetic characteristics, mainly in the non-irrigated seedlings, whose survival at the end of the year after planting was approximately $2.5 \%$. Stone pine and holm oak seedlings responded more to irrigation than to mulching in terms of shoot growth, biomass and survival. Furthermore, stone pine seedlings were found to be more responsive to the partial alleviation of summer drought than holm oak seedlings. Irrigation alone produced similar results to those obtained when both irrigation and mulching were employed. In conclusion, first year summer irrigation should be considered as a planned adaptation measure in the management of outplanted Mediterranean ecosystems, because once a gravimetrically measured soil moisture level as low as $2 \%$ is achieved seedling survival and physiological performance can be guaranteed. However, the repercussions for the potential persistence of both species in the area will not only be related to the recurrence and intensity of summer droughts but also to drought duration.

Keywords: Stone Pine, Holm Oak, Irrigation, Drought, Seedling Survival, Physiological Traits

\section{Introduction}

Successful seedling establishment is the greatest challenge to new plantings in the Mediterranean environment (Ceacero et al. 2012), where seedling mortality rates are generally high after the first summer following outplanting (Chirino et al. 2011). Newly established seedlings must be capable of "coupling" to the forest ecosystem in order to restore their physiological functioning and initiate growth (Grossnickle 2005). Inadequate contact between roots and soil leads to increased water stress, which in turn can result in carbon starvation, hydraulic failure, and consequent seedling death (Gross-

nickle 2012). A delay in such "coupling" can be particularly detrimental in Mediterranean ecosystems, which are characterized by high seasonality and where soil water availability is the primary factor affecting a successful establishment. Factors determining low survival rates and slow growth during the first summer of outplanted Mediterranean species can be highly variable and complex, often involving interaction and mutual influence between factors (Jiménez et al. 2007). These factors include summer drought, excessive solar radiation, nutrient-poor soils, herbivore pressure, and competition with shrubs and herbaceous vegetation. Summer drought,

$\square$ INIA-CIFOR, Crtra Coruña Km 7.5, E-28040 Madrid (Spain)

@ Marta Pardos (pardos@inia.es)

Received: Jan 29, 2014 - Accepted: Jul 20, 2014

Citation: Pardos M, Calama R, Mayoral C, Madrigal G, Sánchez-González M, 2015. Addressing post-transplant summer water stress in Pinus pinea and Quercus ilex seedlings. iForest 8: 348-358 [online 2014-09-16] URL: http://www.sisef.it/iforest/contents/?id=ifor1256-007

Communicated by: Gianfranco Minotto which is characterized by declining soil water content and increasing vapor pressure deficit, induces stomatal closure, reduces photosynthetic capacity, stomatal conductance and electron transport rates (Craven et al. 2011). According to their drought resistance, plants can be classified as either drought tolerant (achieved by turgor maintenance and/ or desiccation tolerance) or drought avoidant (related to stomatal closure and increased root growth relative to shoots - Levitt 1972).

Different post-planting treatments have been used to improve seedling establishment under Mediterranean conditions: soil preparation (Fonseca et al. 2011), irrigation, mulching, use of nurse plants Gómez-Aparacio et al. 2006), tree-shelters (Pausas et al. 2004), runoff harvesting (Vallejo et al. 2012), neighboring vegetation control Ceacero et al. 2012), fertilization (Villar-Salvador et al. 2012, 2013). The combination of summer irrigation and the use of organic mulch around the newly planted seedlings can potentially increase first year survival and early growth of planted seedlings. Results with regard to the effectiveness of organic mulch in forest plantations have been variable, but in those cases where mulch application positively affected growth, this was attributed to reduced soil water loss (Adams 1997, Cregg et al. 2009) and increased water infiltration (Skroch et al. 1992). The use of irrigation is common in reforestation in Spain, increasing first summer survival and growth under harsh environmental conditions (Rey-Benayas 1998, Rey-Benayas \& Camacho-Cruz 2004, Siles et al. 2010), although due to the increasing economic cost and the concern that watered seedlings display decreased drought tolerance and increased demand for water, this cultural practice is unadvisable. Previous studies have addressed the potential growth response of plantations to irrigation, as well as the physiological mechanisms related to the growth response (Jiménez et al. 2007, Cobb et al. 2008, Cregg et al. 2009).

Stone pine (Pinus pinea L.) typically forms mixed stands with holm oak (Quercus ilex L.) in the Tiétar and Alberche valleys in central Spain. Most of these stands are located on steep slopes, with sandy soils, under a genuine continental Mediterranean climate, where summer drought is the primary determining factor in the success of vegetation establishment. The traditional, multifunctional management of these stands was based on the production of pine nuts, livestock and holm oak firewood production. However, the dramatic decrease in the use of firewood as a fuel source, the increased risk of wildfire as well as overgrazing and the maintenance of large nut producing trees has led to open pine stands with a dense holm oak coppice understory. Burned areas are commonly oc- 
cupied primarily by holm oak due to its early resprouting capacity, which gives it an advantage over stone pine regeneration, which relies solely on early seed germination from its canopy seedbank (Pausas et al. 2004) Hence, the prevalence of stone pine is declining in these burned areas, although the failure of stone pine regeneration to recruit is not fully understood, particularly since residual large parent producer trees ("green is lands") can be found (Montero et al. 2003). Moreover, individual stone pine trees or groups of trees usually survive in burned areas because of their thick bark and their umbrella-like shape (Rodrigo et al. 2007). In summer 2003, 600 ha of these mixed stands were burned. Since then, the Regional Forest Service has repeatedly tried to reforest the area with stone pine seedlings. However even where summer irrigation has been used, none of these efforts have been successful to date. Heavy losses of plants have occurred through desiccation in the dry season as transplants were carried out in open, fully sun-exposed sites.

To determine the potential of summer irrigation and the application of pine bark mulch as treatments for improving first-year planting success in a burned area, we established a stone pine-holm oak plantation trial study in the western part of Madrid. Both species are particularly susceptible in summer to the high irradiances and drought conditions, which are quite different from the shaded and well-watered conditions in the nursery where they were grown. Under frequent water-limiting conditions, Mediterranean plants have adapted to optimize wate use, allowing them to survive and grow (Chaves et al. 2002). In the open conditions of plantations, there is scarce shade to mitigate the impacts of summer drought stress on seedling survival and growth (Holmgren 2000, Sack \& Grubb 2002, Quero et al 2006). Interspecific differences in morphological and physiological responses to summer drought stress will likely modulate seedling growth (Craven et al. 2011, Grossnickle 2012). The ability of both species to adjust physiologically to field conditions will indicate their different degree of acclimation and this may serve to enhance the seedling establishment success rate in reforestation (Gyimah \& Nakao 2007, Vallejo et al. 2012). Both species need a deep, soft soil, with some plant cover to retain soil moisture (Costa et al. 1997, David et al. 2004). If the water table is absent and precipitation is scarce, as occurs in the study area, irrigation will partially compensate such water deficit.

The aim of this experiment was to define a reforestation strategy for this burned area. Prior to setting up the experiment, the area was occupied by approximately $10-15 \%$ of the originally planted pine seedlings and a sprouted holm oak and rockrose (Cistus la- danifer) understory that is slowly colonizing the whole burned area. The objective was to determine how summer irrigation and pine bark mulch can ameliorate the impact of summer drought on first-year survival and to identify the morphological and physiological responses of the plants, which in turn might explain the underlying mechanisms that enable stone pine and holm oak to withstand transplant. The specific objectives were: (1) to compare the effect of post-planting treatments on seedling survival and performance; (2) to determine the different physiological ability of each species to recover once water stress is alleviated; (3) to compare stone pine and holm oak with respect to their acclimation to summer drought; and (4) to identify their strategies to withstand summer drought. Thus, we attempt to determine whether one species outperforms the other in terms of seedling survival, growth or physiology.

\section{Materials and Methods}

\section{Study site}

The study site is located west of Madrid $\left(40^{\circ} 23^{\prime} 25^{\prime \prime} \mathrm{N}, 4^{\circ} 18^{\prime} 7^{\prime \prime} \mathrm{W}\right)$ at $650 \mathrm{~m}$ a.s.1. Mixed stands of stone pine (Pinus pinea L.) and holm oak (Quercus ilex L.) occupy approx. 19000 ha on the rocky granitic slopes that define the valleys of the Alberche and Tiétar rivers. The orography is characterized by a succession of hills and small valleys, with steep slopes defining an abrupt landscape (Calama \& Montero 2007). Soils are poor, mostly sandy, with high presence of granite rocks in the surface layers. The long history of human-induced disturbances (mainly overgrazing and wildfires) has led to a relatively low vegetation cover composed of an understory of resprouted holm oak and rockrose and large areas of bare soil exposed to full sunlight. The climate is continental Mediterranean (annual precipitation is 745 $\mathrm{mm}$ and mean annual temperature is 12.5 $\left.{ }^{\circ} \mathrm{C}\right)$, defined by long, hot and dry summers (mean monthly precipitation from June to September is around $20 \mathrm{~mm}$ ) along with irregular and scarce autumn and spring precipitations. Mean monthly temperatures during the study period (March to December 2011) were similar to historical means, but precipitation was $49 \%$ lower (Fig. 1a, Fig. 1b).

\section{Treatments}

Stone pine and holm oak seeds were collected at the study site and sown in autumn 2010 in FP-300 containers. Seedlings were grown under standard operational conditions (peat substrate, slow releasing fertilizer, irrigation to field capacity). In March 2011, pairs of these stone pine and holm oak containerized seedlings were hand planted into the same hole $\left(200\right.$ holes in total, $0.5 \mathrm{~m}^{2}$, 200 stone pine seedlings and 200 holm oak seedlings) in a steeply sloping (62.2\%) area of 1.1 ha. Mean height of seedlings when planted was $12.4 \pm 1.6 \mathrm{~cm}$ (stone pine) and $14.6 \pm 3.3 \mathrm{~cm}$ (holm oak). The trial was established within the perimeter of the 600 ha of mixed stands burned in 2003. We used the same planting holes that had been repeatedly used in previous years by the Regional Forest Service for unsuccessful stone pine reforestations. Hand-made planting holes $(0.8 \times 0.7 \times 0.5 \mathrm{~m})$ were arranged in ten rows following contour lines, 20 holes per row. The holes were initially cleared of competing vegetation and no further vegetation control was necessary during the study period. The experiment was setup as a completely randomized design with two factors (irrigation and organic mulching), with two levels per factor (irrigation, $\mathrm{W}_{+} v s$ non-irrigation, $\mathrm{W}_{0}$; mulching, $\mathrm{M}_{+} v s$ non-mulching $\mathrm{M}_{0}$ ), for a total of four treatment combinations: $\mathrm{W}_{0} \mathrm{M}_{0}$ (no irrigation, no mulching), $\mathrm{W}_{0} \mathrm{M}_{+}$(no irrigation, mulching), $\mathrm{W}_{+} \mathrm{M}_{0}$ (irrigation, no mulching) and $\mathrm{W}_{+} \mathrm{M}_{+}$(irrigation and mulching).

Pine bark was used as organic mulching and was applied on June 7 in alternate planting holes (that is, in 100 planting holes: 100 stone pine seedlings and 100 holm oak seedlings). The area covered by the mulching was approximately $0.7 \mathrm{~m}$ diameter and 20 $\mathrm{cm}$ deep, around the seedlings. Mean length and diameter of pine bark granules were 2.0 $\mathrm{cm}$ and $0.8 \mathrm{~cm}$, respectively. Irrigation started on July 20 because due to severe summer water restrictions in the region, irrigation of afforested stands is only permitted after a month without rainfall and a mean temperature above $20^{\circ} \mathrm{C}$. Seedlings still alive by July 20 (138 stone pine seedlings and 99 holm oak seedlings) were randomly divided into two groups, one of which was irrigated every 7 days until September $15\left(\mathrm{~W}_{+}, 69\right.$ stone pines seedlings and 49 holm oak seedlings) and the other group was treated under natural drought conditions $\left(\mathrm{W}_{0}, 69\right.$ stone pines seedlings and 50 holm oak seedlings). Forty $1 \mathrm{~m}^{-2}$ of water was added on every irrigation date.

\section{Measurements and harvests}

Hemispherical photographs were taken to characterize the light environment at each planting hole. A global site factor (GSF, \%) was calculated at each planting hole based on a solar transmissivity of 0.8 and 0.1 diffuse:direct radiation (Hemiview 2.1, Canopy Analysis Software, Delta-T Devices Ltd., Burwell, Cambridge, UK). On July 22 and September 23, coinciding with the physiological measurements, soil samples were taken in each planting hole from the first 20 $\mathrm{cm}$, and surface soil moisture was calculated gravimetrically. This soil moisture calculation was used as a proxy of plant water status, which reflects the extent of water stress (Bellot \& Ortiz de Urbina 2008) because seedlings had no lateral branches to carry out 
destructive measurements of leaf water potential. To characterize the environmental conditions in the study area, air temperature and relative humidity at a height of $20 \mathrm{~cm}$ above the ground and soil water content at a depth of $20 \mathrm{~cm}$ were continuously monitored using a HOBO micro-weather station (Micro-HWS, ONSET, MS, USA).

Survival was monitored every 25-30 days from May 9 to July 20, every 7 days during the irrigation period irrigation, and every 15 days once irrigation ceased and until the end of the experiment on December 12. Initial seedling height $(\mathrm{H})$ and root collar diameter (d) were measured one week after planting. In addition, seedling height and root collar diameter were measured after the mulching application (June 7), at the beginning and end of the irrigation period (July 20 and September 15), and at the end of the experiment (December 12).

Chlorophyll $a$ fluorescence and gas exchange parameters were measured at midmorning (10 a.m.-12 p.m.) on the main shoot of seedlings on two occasions: at the beginning and end of the irrigation period (July 22 and September 23). On July 22, eight stone pine seedlings and 3-4 holm oak seedlings per treatment combination were measured. On September 23 all living seedlings of both species were measured. However, by this date, there were only 1-2 surviving seedlings in $\mathrm{W}_{0} \mathrm{M}_{0}$ and $\mathrm{W}_{0} \mathrm{M}_{+}$, hence, these two treatment combinations were discarded from the statistical analysis. A portable infrared gas analyzer (IRGA LCA 4 Analytical Development Corporation, UK) was used to measure photosynthesis $\left(A n, \mu \mathrm{mol} \mathrm{CO}_{2} \mathrm{~m}^{-2} \mathrm{~s}^{-1}\right)$ and stomatal conductance $\left(g_{\mathrm{s}}, \mathrm{mol} \mathrm{H}_{2} \mathrm{O} \mathrm{m} \mathrm{m}^{-2} \mathrm{~s}^{-1}\right)$. Photosynthesis $(A n)$ and $g_{\mathrm{s}}$ were expressed on a projected leaf area basis that was determined after harvest. Vapor pressure deficit $(V P D, \mathrm{KPa})$ was calculated from air temperature and relative humidity. Chlorophyll $a$ fluorescence was measured with a portable pulse-modulated fluorometer (FMS 2, Hansatech Instruments Ltd., UK). The yield of photochemistry in PSII ( $\left.\Phi_{\text {PSII }}\right)$ was calculated according to Kramer et al. (2004 - eqn. 1):

$$
\Phi_{P S I I}=\frac{\left(F^{\prime} m-F s\right)}{F^{\prime} m}
$$

where $F^{\prime} m$ is the maximal fluorescence in light and $F_{S}$ is the steady-state light-adapted fluorescence.

Apparent photosynthetic electron transport rate $(E T R)$ at midday was calculated following Rosenqvist \& Van Kooten (2003 - eqn. 2):

$$
E T R=\Phi_{P S I I} \cdot P P F D \cdot 0.84 \cdot 0.5
$$

where $P P F D$ is the photosynthetic photon flux density.

Whole-seedling harvests were conducted on June 7 (to obtain initial dry mass before

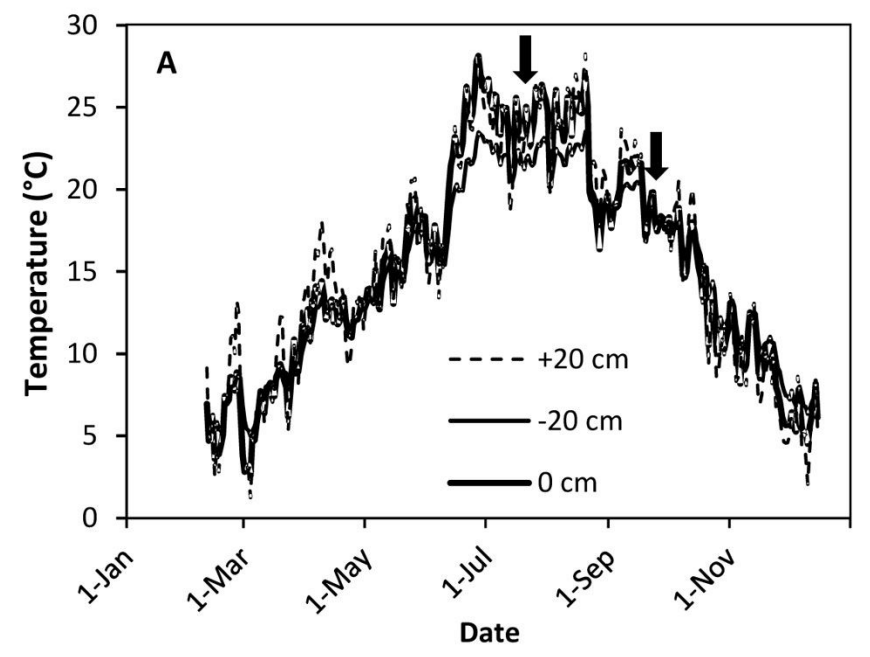

Fig. 1 - (A) Air temperature $(+20$ $\mathrm{cm})$, soil temperature at the surface $(0 \mathrm{~cm})$ and soil temperature at $20 \mathrm{~cm}$ deep $(-20 \mathrm{~cm})$ in 2011; (B) monthly rainfall in $2011 v s$. mean monthly rainfall in the 1978-2010 period; and (C) daily soil moisture (thick line) and daily rainfall (dashed line) during 2011 in

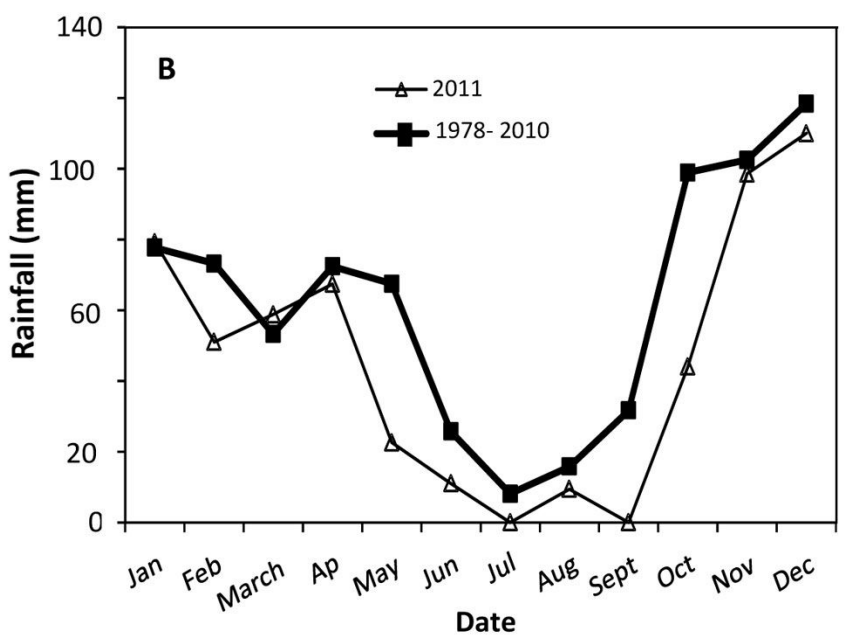
the area of study. Arrows indicate when the physiological measurements were done (July 22 and September 23)

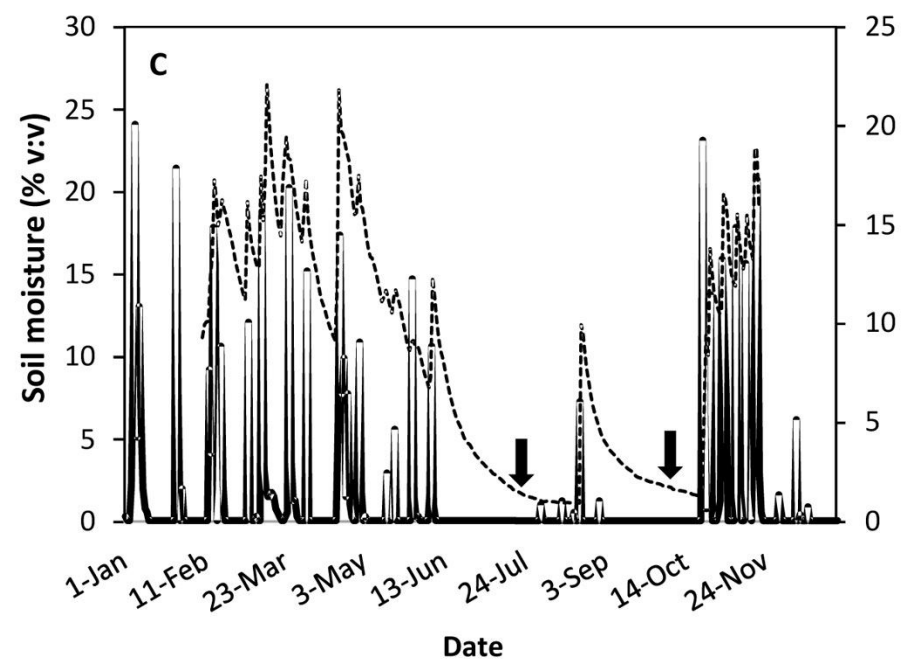

mulching application) and December 12 (end of the experiment). Six to eight seedlings were harvested on June 7 , and almost all living seedlings (18 stone pine seedlings and 9 holm oak seedlings, corresponding to $\mathrm{W}_{+} \mathrm{M}_{+}$and $\mathrm{W}_{+} \mathrm{M}_{0}$ ) were harvested on December 12. At both harvests, seedlings were excavated and stored on ice until they were processed. Seedlings were dried in a forced- air oven at $70{ }^{\circ} \mathrm{C}$ until constant mass and weighed (total, $T D W$ and root, $R D W$ ). Relative root growth rate $(R G R)$ was calculated between June 7 and December 12, as described in Hunt et al. (2002). The ratio between root dry weight and total dry weight $(R M R=$ $R D W / T D W$ ) was also calculated. 


\section{Statistical analysis}

Total biomass $(T D W)$ and root biomass $(R D W)$ were related to height $(H$, in $\mathrm{mm})$ and root collar diameter $(d$, in $\mathrm{mm})$ through a linear function adjusted for our data, according to Ruiz-Peinado et al. (2011), in order to estimate biomass weight over time (eqn. 3 , eqn. 4 )

$$
\begin{gathered}
T D W=0.808+0.033 \cdot d \cdot H \\
\left(R^{2}=0.32, P<0.001\right) \\
R D W=0.345+0.009 \cdot d \cdot H \\
\left(R^{2}=0.25, P<0.01\right)
\end{gathered}
$$

for Pinus pinea and (eqn. 5, eqn. 6):

$$
\begin{gathered}
T D W=1.472+0.038 \cdot d \cdot H \\
\left(R^{2}=0.20, P<0.01\right) \\
R D W=1.216+0.017 \cdot d \cdot H \\
\left(R^{2}=0.38, P<0.01\right)
\end{gathered}
$$

for Quercus ilex.

Shoot height, root collar diameter, tota biomass growth and root biomass over time were analyzed through a general mixed model for repeated measurements (Verbeke \& Molenberghs 2000). A logarithm model was fitted to the data (eqn. 7):

$$
Y_{i j}=\beta_{0 i}+\beta_{1 i} t_{j}+\varepsilon_{i j}=\beta_{0}+u_{i}+\left(\beta_{1}+v_{i}\right) t_{j}+\varepsilon_{i j}
$$

where $Y_{\mathrm{ij}}$ is height, or root collar diameter, or total biomass, or root biomass for the $i$-th individual measured at time $t_{\mathrm{j}}(i=1, \ldots, N ; j=1$, $\left.\ldots, n_{\mathrm{i}}\right) ; t_{\mathrm{j}}$ indicates the logarithm of the number of days from the start of the mulching treatment (92 days from plantation, $t_{\mathrm{j}}=\log$ (measuring date-91); intercepts $\beta_{0 \mathrm{i}}$ and time effect slopes $\beta_{1 \mathrm{i}}$ are divided into a common population fixed component $\beta_{0}$ and $\beta_{1}$, defining population marginal response; and random plant specific parameters $u_{\mathrm{i}}$ and $v_{\mathrm{i}}$, characterize subject-specific individual response (Verbeke \& Molenberghs 2000). Contrast for homogeneity of slopes between the different levels of treatments (irrigation: W, mulching: $\mathrm{M}$, and their interaction: $\mathrm{W} \times \mathrm{M}$ ) was also carried out. Preliminary analysis revealed no differences between intercepts associated with treatment effects.

Seedling physiology was tested separately for each species and measuring date. For the July 22 measurement, a two-way analysis of variance was tested, while on September 23 it was only possible to test the effect of mulching on the irrigated seedlings because of the lack of sufficient replicates in the nonirrigated treatment. Significant differences between treatments within the same species and day of measurement were evaluated by a multiple means comparison test. In addition, we defined the vigor status as the quotient (rate between 0 and 1) between the percentages of green leaves within a seedling in two successive survival measurements. This quotient is an indicator of the loss of seedling vigor and was calculated over the periods July 20 - August 4 and September 15 -
29. The relationship between the vigor status on these dates and both the net assimilation rate measured on July 22 and September 23 for each plant and soil moisture in the planting hole was evaluated by fitting a logistic function and comparing fitted parameters and pattern of survival between species.

In the analysis of seedling survival, we must consider that our data included two kinds of censoring. Some seedlings $(n=12$ holm oak; $n=37$ stone pine) survived the entire period (i.e., right censored), while for the rest of seedlings $(n=178$ holm oak; $n=$ 162 stone pine) we only know the interval in which they died (i.e., interval censored) and the length of the interval (between 6 and 42 days). Since our aim is to determine the effect of irrigation and mulching on seedling survival, we consider survival time to be the period between the mulching application and seedling death or until the end of experiment. The survival analysis was then performed in three steps. In a first step, we estimated and represented the survival distribution of stone pine and holm oak seedlings in each treatment using a nonparametric maximum likelihood estimator (NPMLE), which is computed through the algorithm developed by Wellner \& Zhan (1997). In a second step, we used two generalized log-rank tests developed for interval-censored failure time data to test the hypothesis of whether there was a significant treatment effect or not (Zhao \& Sun 2004, Sun et al. 2005). These two firsts steps of the survival analysis were implemented in SAS using the macros developed by So \& Johnston (2010). Finally, to get an estimate of the treatment effect and to adjust the analysis for other covariates, we fitted a parametric model for interval-censored survival data with time-dependent covariates (Sparling et al. 2006) using a regression approach based on the Weibull distribution as implemented in the SAS macro written by Bautista \& Sparling (2009). The regression model used (i) treatments: irrigation (1 when irrigated, 0 otherwise), mulching (1 if mulching, 0 otherwise), (ii) seedling traits: initial seedling height and root collar diameter measured at mulching treatment, and (iii) environmental covariates: global site factor, soil water content, and daily values of relative humidity, maximum air temperature and vapor pressure deficit.

All computations were performed in SAS version 9.2 software (SAS Institute, Cary, $\mathrm{NC}, \mathrm{USA}$ )

\section{Results}

\section{Environmental data}

The year 2011 was particularly dry during late spring, summer, and early autumn in comparison with the previous 12 years (Fig. 1b). The last rainfall event $(>0.5 \mathrm{~mm})$ in late spring occurred on June 7 followed by a pe- riod of 54 days with no rain. Four rainfall events during August $(9.4 \mathrm{~mm}$ in total) did not alleviate dry soil conditions, which persisted until October 23 (Fig. 1c). Total rainfall between June 7 and October 22 was 10.2 $\mathrm{mm}(2.3 \%$ of total annual rainfall in 2011). Relative air humidity during this period was $44.7 \pm 0.96 \%$ (data not shown), which corresponded to a daytime $V P D$ of $2.9 \pm 0.09$ $\mathrm{KPa}$ (data not shown). Soil water content at a depth of $20 \mathrm{~cm}$ fell by $85.3 \%$ between March and almost the end of October (Fig. 1c). The irrigation treatments during the summer months successfully raised the soil water moisture content relative to non-irrigated planting holes. Surface soil water content calculated on the dates of the physiological measurements was positively affected by both irrigation $(p<0.001)$ and mulch $(\mathrm{p}<0.01$ - Fig. $2 \mathrm{~F})$. Although irrigation reduced soil temperature slightly, differences between treatments were not significant (data not shown). Mean GSF in the plot (used to characterize the light environment) was $0.80 \pm 0.01$, i.e., plants grew under full sunlight.

\section{Shoot height, root collar diameter and biomass over time}

Significant increases $(\mathrm{p}<0.001$, Tab. 1) were recorded in seedling height (between $5.6 \%$ and $14.7 \%$ in stone pine and between $5.6 \%$ and $16.1 \%$ in holm oak, Fig. 3) and root collar diameter (between 18.2\% and $21.3 \%$ in stone pine and $12.7 \%$ and $20.1 \%$ in holm oak, data not shown) over time. The initial difference in height between species $(159.3 \mathrm{~mm}$ for stone pine and $173.1 \mathrm{~mm}$ for holm oak, $\mathrm{p}<0.001$ ) was maintained until the end of the experimental period. Irrigation had a significant and positive effect over time on stone pine shoot height growth, regardless of mulching $(p<0.001$, Tab. 1, Fig. $3)$. The effect of time $(p<0.001)$ and the mulching $\times$ irrigation interaction $(\mathrm{p}<0.05)$ was significant for holm oak shoot height growth (Tab. 1). For both species, there was no significant treatment effect on root collar diameter growth over time (Tab. 1). For both species there was a significant positive effect of time $(p<0.001)$ and a slight effect of irrigation over time $(p<0.1)$ on total biomass $(T D W)$, with no significant mulching effect (Tab. 1, Fig. 3). In addition, irrigated stone pine seedlings significantly increased $(\mathrm{p}<$ 0.001 , Tab. 1, Fig. 3) their root biomass $(R D W)$ over time $(16.4 \%$ increase in irrigated seedlings vs $12 \%$ in non-irrigated seedlings). By the end of the experiment, holm oak seedlings showed higher $R D W(\mathrm{p}<0.001$, $\left.R D W_{\text {holm oak }}=3.59 \mathrm{~g}, R D W_{\text {stone pine }}=1.19 \mathrm{~g}\right)$ and root mass ratio $(R M R, \mathrm{p}<0.001$, $R M R_{\text {holm oak }}=0.59 \pm 0.07 \mathrm{~g} \mathrm{~g}^{-1}, R M R_{\text {stone pine }}=$ $0.350 \pm 0.08 \mathrm{~g} \mathrm{~g}^{-1}$ ) than stone pine seedlings; however, by December 12, root growth rate $(R G R)$ of stone pine seedlings was higher 
Fig. 2 - Mean physiological parameters and soil moisture measured on July 22 and September 23 for each treatment combination: (A) net assimilation rate $\left(A n, \mu \mathrm{mol} \mathrm{m}^{-2} \mathrm{~s}^{-1}\right)$; (B) transpiration rate $\left(E, \mathrm{mmol} \mathrm{m}^{-2} \mathrm{~s}^{-1}\right) ;(\mathrm{C})$ stomatal conductance $\left(g_{\mathrm{s}}, \mathrm{mol}\right.$ $\left.\mathrm{m}^{-2} \mathrm{~s}^{-1}\right)$; (D) yield of photochemistry in PSII ( $\left.\Phi_{\mathrm{PSII}}\right)$; (E) apparent photosynthetic electron transport rate $(E T R)$; and (F) mean soil moisture per treatment (\%).

Physiological parameters were measured separately in Pinus pinea and Quercus ilex seedlings, while soil moisture represents the mean value for each planting hole where a pair of Pinus pinea and Quercus ilex seedlings was planted. For the physiological parameters, different letters show significant differences in July between treatment combinations for each species. For soil moisture, different letters show significant differences between treatment combinations and measurement day (no letter is shown for $\mathrm{W}_{0} \mathrm{M}_{0}$ in September, because the value refers only to one planting hole). P-values show the effect of irrigation in July and the effect of mulch for irrigated seedlings in September. No letter separation is included in September as only two treatments are shown.
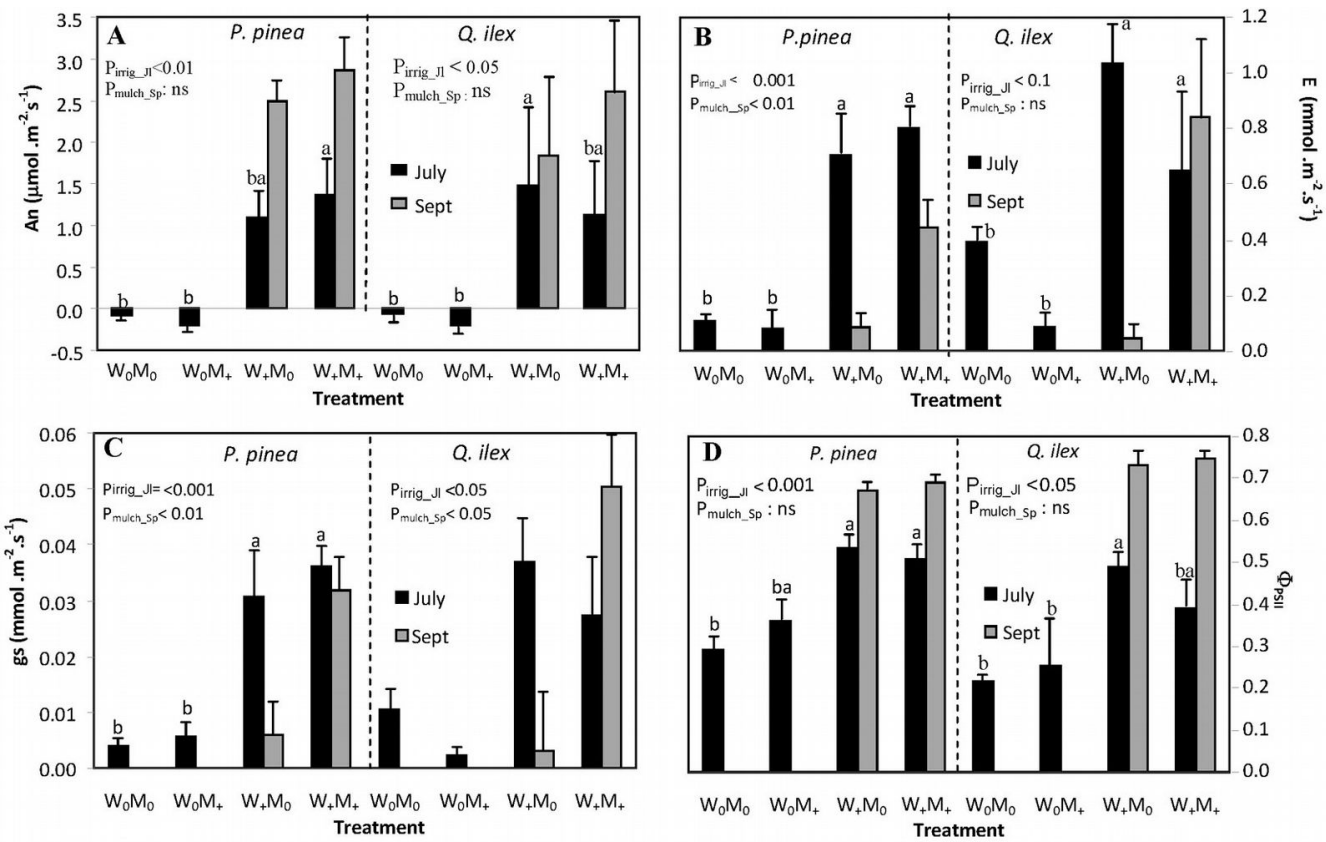

$\begin{array}{llllllll}W_{0} M_{0} & W_{0} M_{+} & W_{+} M_{0} & W_{+} M_{+} & W_{0} M_{0} & W_{0} M_{+} & W_{+} M_{0} & W_{+} M_{+}\end{array}$ Treatment
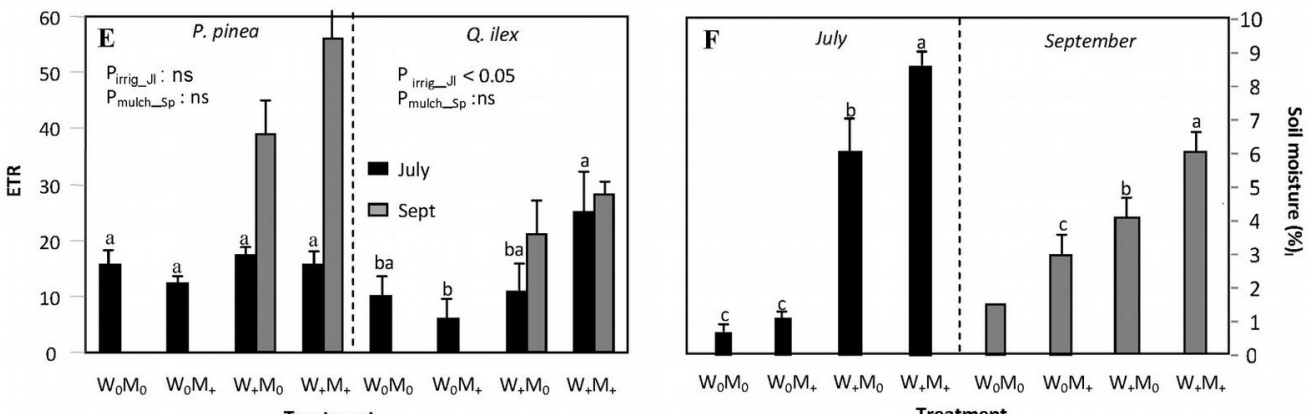

Treatment than that of holm oak $\left(R G R_{\text {holm oak }}=0.00027\right.$ day $^{-1}, R G R_{\text {stone pine }}=0.00033$ day $\left.^{-1}, \mathrm{p}<0.01\right)$.

\section{Gas exchange and chlorophyll \\ fluorescence}

Gas exchange and chlorophyll fluorescence measurements (Fig. 2) were intimately related to environmental conditions at the time of measurement (Fig. 1). In July, the effect of irrigation on stone pine seedling physiology was significant irrespective of mulching. Net photosynthetic rate $(A n)$ was the most responsive parameter to irrigation, being $97 \%$ lower in non-irrigated than in irrigated stone pine seedlings $\left(1.22\right.$ in $\mathrm{W}_{+} v s-0.13$ $\mu \mathrm{mol} \mathrm{m} \mathrm{m}^{-2} \mathrm{~s}^{-1}$ in $\mathrm{W}_{0}$ ). Values of the physiological parameters in non-irrigated stone pine seedlings were $88 \%$ lower for transpiration rate $\left(E: 0.75\right.$ in $\mathrm{W}_{+} v s 0.09 \mathrm{mmol} \mathrm{m}^{-2} \mathrm{~s}^{-1}$ in $\left.\mathrm{W}_{0}\right), 86 \%$ lower for stomatal conductance ( $g_{\mathrm{s}}: 0.033$ in $\mathrm{W}_{+} v s 0.0048 \mathrm{~mol} \mathrm{~m}^{-2} \mathrm{~s}^{-1}$ in $\mathrm{W}_{0}$ ), and $38 \%$ lower for the yield of photochemistry in PSII ( $\Phi_{\text {PSII }}: 0.52$ in $\mathrm{W}_{+} v s 0.33$ in $\mathrm{W}_{0}$ ), in comparison to irrigated seedlings. Irrigation in July affected positively $A n(137 \%$ increment compared to non-irrigated seedlings,
Tab. 1 - Results of the shoot height, root collar diameter growth, total dry weight and root dry weight over time analyzed by a general mixed model for repeated measurements in Pinus pinea and Quercus ilex. The general structure for the general mixed model is shown in eqn. 1: $Y_{\mathrm{ij}}=\beta_{0 \mathrm{i}}+\beta_{1 \mathrm{i}} \cdot t_{\mathrm{j}}+\varepsilon_{\mathrm{ij}}$, where $t_{\mathrm{j}}$ indicates the number of days from the start of the mulching treatment [92 days from plantation; $t_{\mathrm{j}}=\log ($ measuring date - 91)]. (W): irrigation treatment; (M): mulch treatment; (df): degrees of freedom in denominator.

\begin{tabular}{llrrrrrr}
\hline \multirow{2}{*}{ Variable } & Effects & \multicolumn{3}{c}{ Pinus pinea } & \multicolumn{3}{c}{ Quercus ilex } \\
\cline { 3 - 8 } & & df & F-value & P-value & df & F-value & P-value \\
\hline Height & $t_{\mathrm{j}}$ & 105 & 123.27 & $<0.0001$ & 60 & 46.46 & $<0.0001$ \\
& $t_{\mathrm{j}} \times \mathrm{W}$ & 75 & 14.61 & 0.0003 & 32 & 1.25 & 0.2724 \\
& $t_{\mathrm{j}} \times \mathrm{M}$ & 75 & 0.17 & 0.6823 & 32 & 0.06 & 0.8112 \\
& $t_{\mathrm{j}} \times \mathrm{W} \times \mathrm{M}$ & 75 & 2.03 & 0.1587 & 32 & 5.29 & 0.0281 \\
\hline Root collar & $t_{\mathrm{j}}$ & 105 & 93.24 & $<0.0001$ & 60 & 81.47 & $<0.0001$ \\
diameter & $t_{\mathrm{j}} \times \mathrm{W}$ & 75 & 0.08 & 0.7763 & 32 & 1.26 & 0.2703 \\
& $t_{\mathrm{j}} \times \mathrm{M}$ & 75 & 0.25 & 0.6171 & 32 & 0.45 & 0.5061 \\
& $t_{\mathrm{j}} \times \mathrm{W} \times \mathrm{M}$ & 75 & 0.01 & 0.9125 & 32 & 0.65 & 0.4250 \\
\hline Total Dry & $t_{\mathrm{j}}$ & 105 & 147.9 & $<0.0001$ & 60 & 127.13 & $<0.0001$ \\
Weight & $t_{\mathrm{j}} \times \mathrm{W}$ & 75 & 3.61 & 0.0611 & 32 & 2.9 & 0.0980 \\
& $t_{\mathrm{j}} \times \mathrm{M}$ & 75 & 0.05 & 0.8270 & 32 & 0.2 & 0.6613 \\
& $t_{\mathrm{j}} \times \mathrm{W} \times \mathrm{M}$ & 75 & 0.06 & 0.8048 & 32 & 0.71 & 0.4069 \\
\hline Root Dry & $t_{\mathrm{j}}$ & 105 & 150.25 & $<0.0001$ & 60 & 118.82 & $<0.0001$ \\
Weight & $t_{\mathrm{j}} \times \mathrm{W}$ & 75 & 3.73 & 0.0571 & 32 & 2.35 & 0.1348 \\
& $t_{\mathrm{j}} \times \mathrm{M}$ & 75 & 0.04 & 0.8378 & 32 & 0.47 & 0.4966 \\
& $t_{\mathrm{j}} \times \mathrm{W} \times \mathrm{M}$ & 75 & 0.05 & 0.8190 & 32 & 0.72 & 0.4021 \\
\hline
\end{tabular}




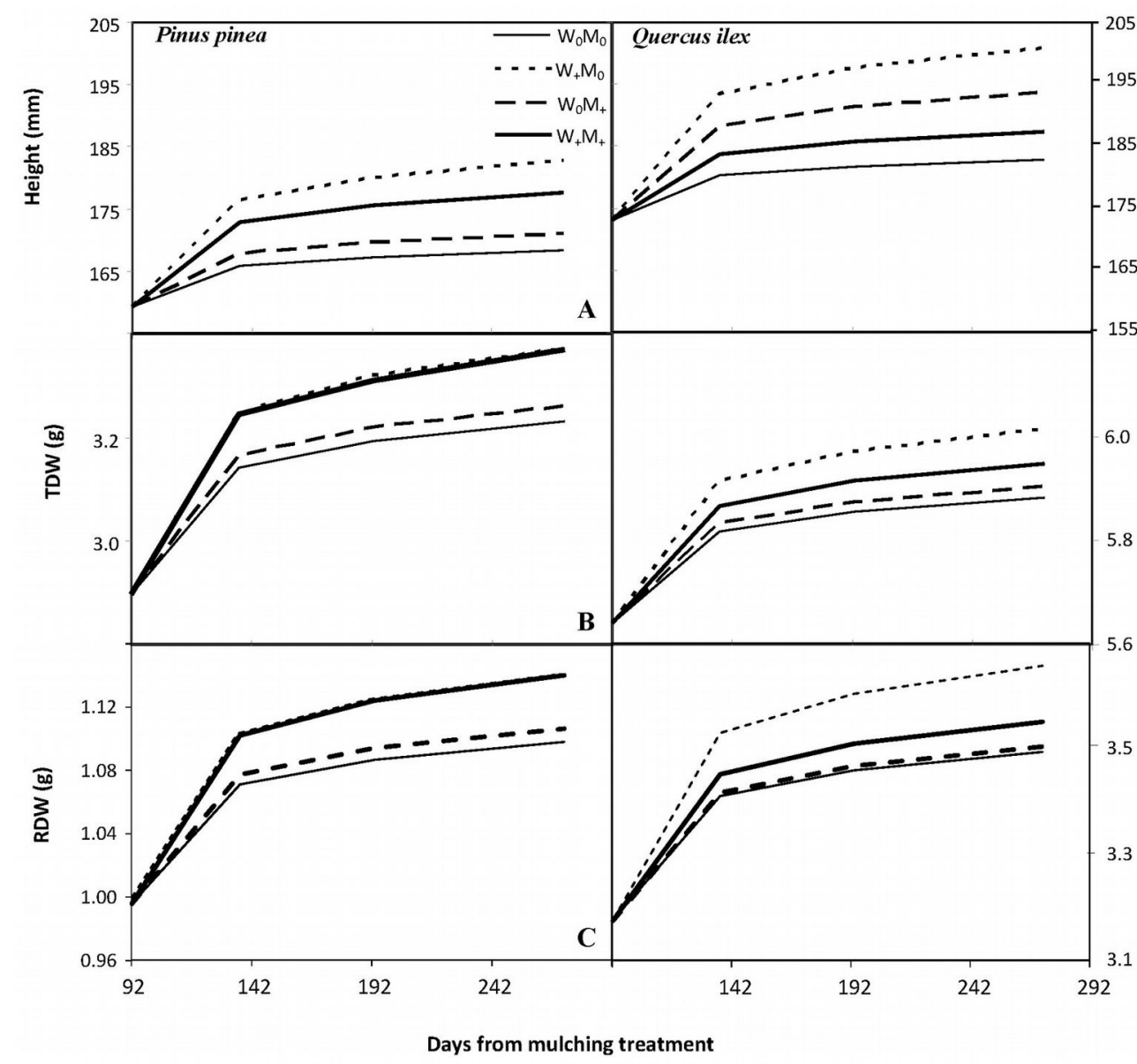

Fig. 3 - Population marginal response of (A) shoot height (mm), (B) total biomass $(T D W, \mathrm{~g})$ and $(\mathrm{C})$ root biomass $(R D W, \mathrm{~g})$ over time for each 55 treatment and species. The general structure of the mixed model is 75 shown in eqn. 1, while population marginal response is given by $Y_{\mathrm{i}}=\beta_{0}$ $165+\beta_{1} \log \left(t_{\mathrm{j}}\right)$, where $t_{\mathrm{j}}$ indicates the number of days from the start of the 55 mulching treatment ( 92 days from plantation, $t_{\mathrm{j}}=$ measuring date -91$)$. Scale of the $y$-axis for $T D W$ and 6.0 $R D W$ is different on both species for clarity.

0.98 in $\mathrm{W}_{+} v s-0.1346 \mu \mathrm{mol} \mathrm{m} \mathrm{m}^{-2} \mathrm{~s}^{-1}$ in $\left.\mathrm{W}_{0}\right), g_{\mathrm{s}}$ (82\% increment, 0.032 in $\mathrm{W}_{+}$vs $0.006 \mathrm{~mol}$ $\mathrm{m}^{-2} \mathrm{~s}^{-1}$ in $\left.\mathrm{W}_{0}\right), \Phi_{\mathrm{PSII}}(45 \%$ increment, 0.434 in $\mathrm{W}_{+} v s 0.238$ in $\left.\mathrm{W}_{0}\right)$ and apparent photosynthetic electron transport rate (ETR: $45 \%$ increment, 18.7 in $\mathrm{W}_{+} v s 7.7$ in $\mathrm{W}_{0}$ ) in holm oak seedlings. Holm oak showed higher transpiration rates $(62 \%$ higher, $\mathrm{p}<0.01)$ and stomatal conductance $(64 \%$ higher, $\mathrm{p}<0.05)$ than stone pine in the absence of treatment (i.e., $\mathrm{W}_{0} \mathrm{M}_{0}$ ). By September, net photosynthetic rates were positive for all seedlings measured. The irrigated stone pine seedlings grown with mulching showed significantly

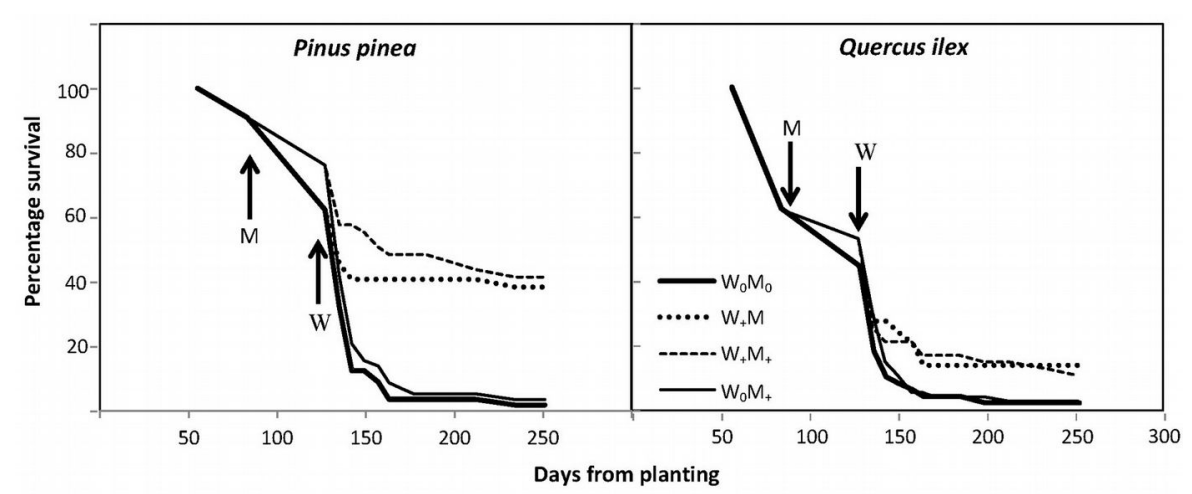

Fig. 4 - Percentage of survival of Pinus pinea and Quercus ilex over time, according to treat-

ment. Arrows indicate when the mulching (M) and irrigation (W) treatments started.

higher values of $E\left(0.44\right.$ in $\mathrm{M}_{+} v s \quad 0.084$ $\mathrm{mmol} \mathrm{m} \mathrm{m}^{-2}$ in $\left.\mathrm{M}_{0}\right)$ and $g_{\mathrm{s}}\left(0.032\right.$ in $\mathrm{M}_{+} v s$ $0.006 \mathrm{~mol} \mathrm{~m}^{-2} \mathrm{~s}^{-1}$ in $\mathrm{M}_{0}$ ) than irrigated seedlings with no mulching. The effect of mulching on irrigated holm oak seedlings was significant for $g_{\mathrm{s}}\left(0.05\right.$ in $\mathrm{M}_{+} v s 0.003 \mathrm{~mol}$ $\mathrm{m}^{-2} \mathrm{~s}^{-1}$ in $\mathrm{M}_{0}$ ). No differences between species were found in September.

\section{Seedling survival}

Seedling survival over time was higher in the irrigated seedlings, mainly in stone pine. When the irrigation treatment commenced, survival ranged from 44 to $53 \%$ in holm oak and from 62 to $76 \%$ in stone pine, the higher values always corresponding to seedlings grown with mulching. Final survival rates in December 2011 were $12.2 \%$ in irrigated seedlings and $2.4 \%$ in non-irrigated seedlings for holm oak, and $39.9 \%$ in irrigated seedlings and $2.6 \%$ in non-irrigated seedlings for stone pine (Fig. 4, Tab. 2). The few non-irrigated seedlings of each species that survived were located in a more favorable microenvironment, with $G S F \approx 0.5-0.7$. In those holes where only one of the species survived and grew, no effect of the lack of competition for nutrients and water was observed.

The generalized log-rank test results confirmed a statistically significant difference between treatments, which was more significant in stone pine $(\mathrm{p}<0.001$, for both tests $)$ than in holm oak $(\mathrm{p}<0.01$ for the test of Zhao $\&$ Sun (2004), and $p<0.01$ for the test of Sun et al. (2005)). Results show that mulching was not a significant predictor of survival once irrigation was applied. The Weibull scale parameters were significantly greater than 1 for both species, which means that the rate of death decreases with time (Tab. 2). Besides the irrigation treatment, stone pine seedling survival was significantly influenced by initial height and daily maximum temperature. The value of the coefficient of 
daily maximum temperature was 0.2740 , which meant that the risk of death is 1.31fold $[=\exp (0.2740)]$ higher per unit increase in daily mean temperature, while all other covariates are held constant. Initial seedling height had a smaller effect on risk, with 0.98 -fold decrease in risk per unit increase in height. For holm oak, irrigation treatment and $G S F$ had a significant effect on the risk of death, the greatest effect being exerted by $G S F$, with a 2.84 -fold increase in risk per unit increase in $G S F$, all else remaining equal.

Vigor status versus photosynthetic rate (An) and soil moisture

The photosynthetic rate $(A n)$ measured on July 22 and September 23 was significantly $(p<0.001)$ related to the vigor status of seedlings in the following weeks, the response being similar for both species $(\mathrm{p}>0.5)$. Values of $A n$ greater than $1 \mu \mathrm{mol} \mathrm{m} \mathrm{m}^{-2} \mathrm{~s}^{-1}$ for holm oak and greater than $1.5 \mu \mathrm{mol} \mathrm{m}^{-2} \mathrm{~s}^{-1}$ for stone pine guaranteed a vigor status of 0.8 , although these $A n$ values were only reached in irrigated seedlings (Fig. 5A). Conversely, negative rates of net assimilation led to a decrease in the vigor status to values below $0.3-0.4$, endangering seedling
Tab. 2 - Parameter estimates, standard errors, Wald tests and hazard ratios of the Weibull seedling survival model for both species. (GSF): Global Site Factor; Diameter (mm); Height $(\mathrm{mm})$; (Tmax): daily maximum temperature $\left({ }^{\circ} \mathrm{C}\right)$; $(\mathrm{VPD})$ : vapor pressure deficit $(\mathrm{KPa})$; $(\mathrm{RH})$ : air relative humidity $(\%)$; $(\mathrm{SWH})$ : soil water humidity calculated gravimetrically.

\begin{tabular}{llrrrrl}
\hline \multirow{2}{*}{ Species } & Parameter & Estimate & Standard & \multicolumn{2}{c}{ Wald } & Hazard \\
P. pinea & Intercept & -7.4683 & 4.7063 & 2.5182 & 0.1125 & 0.0006 \\
& Irrigation & -1.6929 & 0.2532 & 44.6987 & $<0.0001$ & 0.184 \\
& GSF & 1.0677 & 0.7407 & 2.0779 & 0.1494 & 2.9087 \\
& Height & -0.0168 & 0.0051 & 10.9652 & 0.0009 & 0.9834 \\
& Diameter & -0.2163 & 0.1614 & 1.7974 & 0.18 & 0.8055 \\
& Tmax & 0.274 & 0.0668 & 16.8237 & $<0.0001$ & 1.3153 \\
& VPD & -0.9734 & 0.8598 & 1.2817 & 0.2576 & 0.3778 \\
& RH & 0.0695 & 0.0522 & 1.7748 & 0.1828 & 1.072 \\
& SWH & 0.0198 & 0.0615 & 0.1039 & 0.7472 & 1.02 \\
\hline Q.ilex & Intercept & -13.127 & 10.6246 & 1.5265 & 0.2166 & 0 \\
& Irrigation & -0.7592 & 0.3096 & 6.0123 & 0.0142 & 0.468 \\
& GSF & 1.2146 & 0.3498 & 12.0578 & 0.0005 & 3.369 \\
& Height & -0.0054 & 0.0034 & 2.5391 & 0.1111 & 0.9947 \\
Diameter & 0.2792 & 0.1579 & 3.1266 & 0.077 & 1.322 \\
& Tmax & 0.1024 & 0.3402 & 0.0905 & 0.7635 & 1.1078 \\
& VPD & 1.1204 & 1.3683 & 0.6705 & 0.4129 & 3.066 \\
RH & 0.0677 & 0.0768 & 0.7769 & 0.3781 & 1.0701 \\
& SWH & 0.1283 & 0.2804 & 0.2094 & 0.6473 & 1.1369 \\
\hline
\end{tabular}

Fig. 5 - Relationship of percentage of vigor with: (A) net assimilation rate $(A n)$ measured in Pinus pinea and Quercus ilex seedlings; and (B) soil moisture measured in the planting holes on July 22 and September 23.

Each point represents a measurement of $A n$ or soil moisture for irrigated $\left(\mathrm{W}_{+}\right.$, squares) and non-irrigated ( $\mathrm{W}_{0}$, diamonds) seedlings. All pairs of data for each species were adjusted to a logistic function.
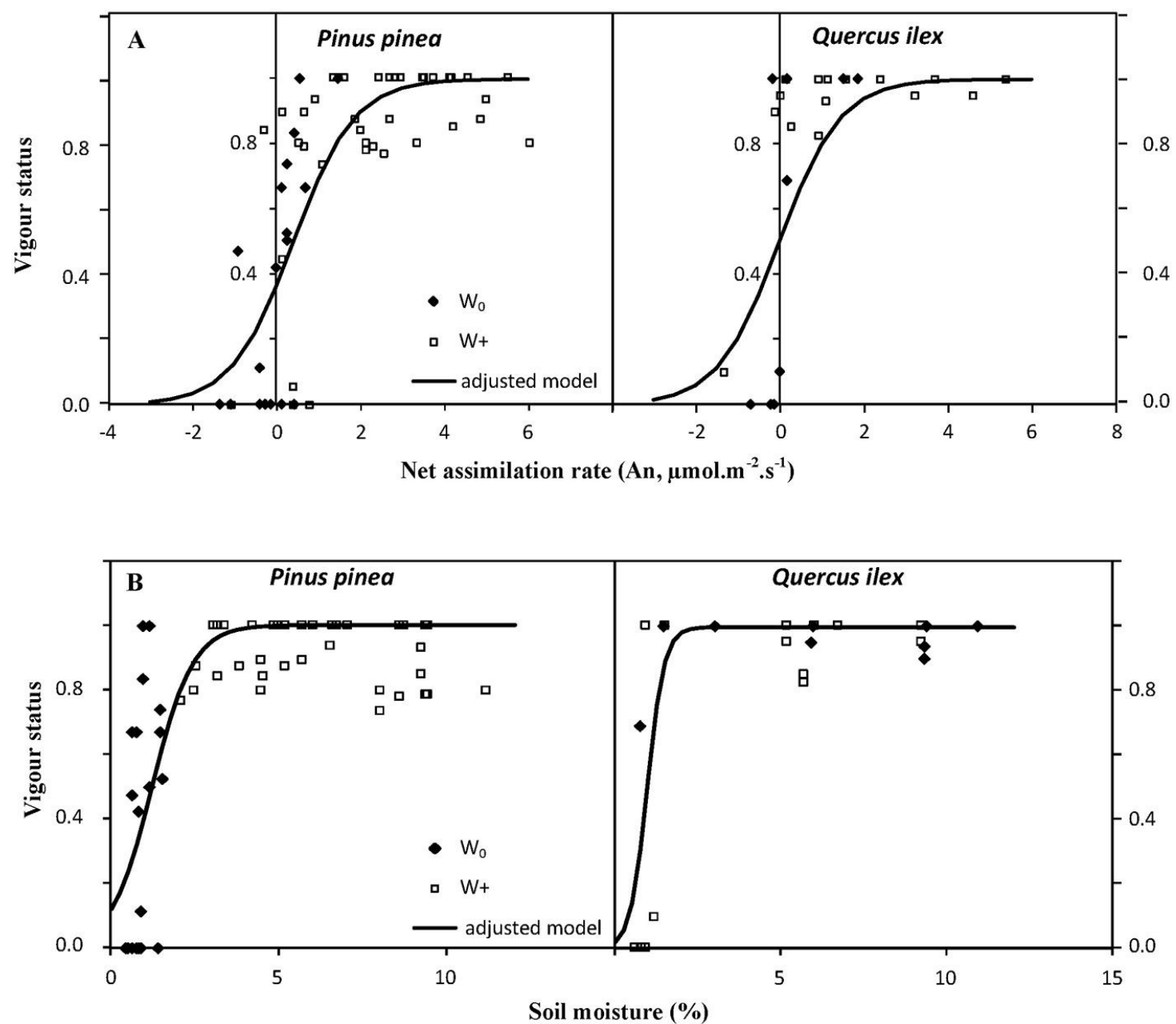
survival. Soil moisture on July 22 and September 23 was also significantly $(\mathrm{p}<0.05)$ related to the vigor status of seedlings in the following weeks. As with $A n$, values of soil moisture in the planting hole of around $2 \%$ guaranteed a vigor status of 0.8 , which again, was only achieved in irrigated planting holes (Fig. 5B).

\section{Discussion}

\section{Effect of irrigation and mulching on} growth, biomass, and survival

Our study revealed contrasting performance and survival responses to irrigation and mulching in stone pine and holm oak seedlings. A clear benefit of irrigation on first summer seedling survival was observed in both species, while the harsh site conditions in the absence of irrigation severely limited seedling survival and left seedlings susceptible to other environmental stresses, which led to reduced seedling growth (Nikiema et al. 2012). Furthermore, irrigation alone produced similar results to those obtained when both irrigation and mulching were employed The scarce effectiveness of mulching alone as a means to improve seedling survival and performance under the water limiting conditions of Mediterranean environments has previously been reported (Jiménez et al. 2007, Siles et al. 2010, Soliveres et al. 2012). Similarly, stone pine seedlings were more responsive to the partial alleviation of summer drought than holm oak seedlings.

The limiting conditions usually found under a Mediterranean summer climate were further aggravated by the exceptionally drought summer conditions in 2011, which was drier than the previous 12-year average, summer rainfall events totaling less than 10 $\mathrm{mm}$, which might be considered too little for the plants to be able to exploit (Vallejo et al 2012). Consequently, survival through the summer was almost entirely limited to irrigated seedlings, and particularly in stone pine seedlings ( $39.9 \%$ survival), the roots of which seemed to display greater effectiveness in initiating growth and "coupling" with into the forest ecosystem than those of holm oak $(12.2 \%$ survival). The ability of seedlings to quickly reach relatively deep and sufficiently moist soil layers reflects seedling functional integrity and vigor (Grossnickle 2012, Vallejo et al. 2012). As seedling survival in Mediterranean environments is linked to root growth achieved by the summer (Villar-Salvador et al. 2012, 2013) and prior to drought occurrence (Navarro et al. 2006), it seems that both species (particularly holm oak) suffered from a combination of high temperature, drought and shallow rooting, which together contributed to high seedling mortality. As with moisture availability, root volume and nutrient uptake are linked; thus, plant water stress may in turn lead to reduced plant nutrient uptake (Dalton \& Messina 1995).

\section{Effects of irrigation and mulching on gas exchange and chlorophyll \\ fluorescence}

Irrigation enabled stone pine and holm oak seedlings to photosynthesize, while negative carbon assimilation rates were shown in nonirrigated seedlings due to stomata closure. The maintenance of positive, albeit low, mid-morning net photosynthesis in July in irrigated seedlings compared to the negative values in the non-irrigated seedlings indicate that the drought-tolerance mechanisms of both species were intimately related to the low water availability by mid-summer. Likewise, high $V P D$ and increased susceptibility to high radiation loads provoked stomatal closure in non-irrigated seedlings, avoiding excessive water loss at mid-morning (Ogaya \& Peñuelas 2003a, Craven et al. 2011, Pardos et al. 2010). Although transpiration is an efficient way to reduce plant temperature, if it is permanently low on summer days with extremely high temperatures, stress from leaf overheating can occur (Kurjak et al. 2012). Non-irrigated holm oak seedlings reached higher $g_{\mathrm{s}}$ and $E$ values in July than stone pine seedlings. These results may suggest a better adaptation of the species to drought and warm conditions (Filella et al. 1998, Gratani \& Bombelli 2000) as well as a more rapid recovery after drought (Galle et al. 2011). However, $g_{\mathrm{s}}$ and $E$ values were not high enough to cope with the drought and heat through the summer of 2011, which led to high mortality in holm oak. The effect of irrigation on fluorescence parameters was in accordance with the $A n, E$, and $g_{\mathrm{s}}$ responses (i.e., drought and light exceeded the capacity of seedlings for carbon assimilation). This energy excess may cause photodamage to the photosynthetic apparatus, which can further compromise the short and mid-term survival of plants growing under full sun (Morison \& Jarvis 1983). Damage to PSII as a result of high temperatures can be more severe when plants are drought stressed (Xu \& Baldocchi 2003), as occurred in this study. The persistence of such limiting drought conditions until October did not allow the recovery of PSII in non-irrigated seedlings, suggesting that photoinhibition was probably a secondary response to water stress and heat (Ogaya et al. 2011), causing the mortality of nearly all $(97 \%)$ of the non-irrigated seedlings by September. The alleviation of drought through the summer in irrigated seedlings led to a recovery in PSII. Furthermore, by September, irrigation and mulching had produced an additive and positive effect on seedling physiology.

The severity of summer conditions was great enough to consistently reduce leaflevel photosynthesis in both species, regard- less of their functional group or successional status. Stone pine behaves similarly to other pine species, which are considered good examples of water use regulation, reducing their stomatal conductance as soil water content declines and atmospheric conditions become drier, while maintaining relatively constant midday water potential values regardless of drought conditions (Calama et al. 2013b, Himmelsbach et al. 2012). On the other hand, the water regulation pattern in holm oak indicates an anisohydric behavior (Andivia et al. 2012), maintaining higher stomatal conductance and allowing midday water potential to decline as soil water content decreases. Measurements of water potential carried out on nearby stone pine and holm oak natural regeneration during the summer of 2011 (July and August) confirmed this behavior $(\Delta \Psi=$ midday water potential - predawn water potential $=0.37 \mathrm{MPa}$ for stone pine; $\Delta \Psi=1.69 \mathrm{MPa}$ for holm oak, unpublished data). Hence, the alleviation of these dry conditions through irrigation was the only way to guarantee seedling survival, stone pine seedlings being more responsive to this treatment. Nevertheless, the physiological responses in mid-summer, though favored by irrigation, rendered limited growth in both species. Summer net photosynthetic rates greater than $1 \mu \mathrm{mol} \mathrm{m} \mathrm{m}^{-2} \mathrm{~s}^{-1}$ in holm oak and greater than $1.5 \mu \mathrm{mol} \mathrm{m}^{-2} \mathrm{~s}^{-1}$ in stone pine were necessary to guarantee a vigor status of 0.8 . However, these values were only reached in the irrigated seedlings, as non-irrigated seedlings showed negative assimilation rates, leading to the death of seedlings within weeks. Interestingly, a gravimetrically measured soil moisture as low as $2 \%$ (that was found in irrigated seedlings) is enough to guarantee a vigor status as high as 0.8 . In our experiment, this soil moisture value could be a more efficient indicator of soil water availability for the dry soil during the 2011 summer drought conditions than predawn water potential, which can differ between plants due to soil heterogeneity (Bellot \& Ortiz de Urbina 2008).

\section{Functional and practical implications for seedling survival and performance}

Seedling survival and growth under a typical dry, sun-drenched summer in the Mediterranean climate is related, among other factors, to canopy cover (Schupp 1995), as excessive light can be a stress factor (Gómez-Aparacio et al. 2006). The concurrence of high radiation and drought during the summer exacerbates the negative impact of drought on plant performance, leading to photoinhibition and thereby further limiting carbon assimilation (Valladares et al. 2005), which can induce starvation-related dieback, cause hydraulic failure and finally plant death (Calama et al. 2013a). Under the particularly harsh environmental conditions pre- 
sent in summer 2011, the few non-irrigated seedlings of each species that survived were located in a more favorable microenvironment, benefiting from some shade provided by the scarce understory vegetation. Under such severe conditions, the differing water status regulation behavior of each species (isohydric behavior in stone pine vs. anisohydric behavior in holm oak) did not appear to confer an advantage of one species over the other. Based on our results, the optimal niche for both species must maximize survival during the summer, avoiding high irradiance and extreme temperatures. These optimal conditions can be achieved most efficiently through a combination of first-year summer irrigation, artificial shading or by planting in specific microsites with partialshade conditions in summer, avoiding the harsh midday sun, while being exposed to full sun during the moist spring period $(\mathrm{Ca}-$ lama et al. 2013a). From our results, firstyear summer irrigation appears to be a good and not excessively expensive option, given that once a value of a gravimetrically measured soil moisture as low as $2 \%$ is achieved, survival will be assured. In addition, the beneficial effect of the below-crown environment is part of the regeneration ecology of stone pine (Manso et al. 2012, 2013, Gordo et al. 2012). Likewise, shrubs, particularly rockrose and broom, play an important role in facilitating holm oak seedling survival, not only by protecting the seedlings from herbivores but also as buffers to stressful factors (Rolo et al. 2013), thereby improving the abiotic conditions. However, this may be insufficient to prevent desiccation in the summer (Badano et al. 2009).

The repercussions for the potential persistence of both species in the area will be longer lasting in the case of stone pine because the resprouting capacity of holm oak provides it with an ecological advantage over the seeded stone pine seedlings. Resprouted individuals can use underground reserves and display an increased capacity to assimilate available water and nutrients as a result of their extensive root systems and small resprouting shoot (Moreira et al. 2009, Guàrdia et al. 2012). Hence, it is likely that in the long term, the climatic constraints (increased probability of drought, heat stress and rising atmospheric $\mathrm{CO}_{2}$ concentration) will influence changes in species distribution (Ogaya \& Peñuelas 2003b). Under these new climatic scenarios, first year summer irrigation of outplanted seedlings (to reach $2 \%$ soil moisture) combined with the establishment of specific shaded microsites for planting that increase spatial heterogeneity in tree pattern should be considered as measures of adaptive management to promote resilient and resistant forested ecosystems (Stephens et al. 2010).

\section{Acknowledgments}

This study was financed by the national project AGL2010-15521 and the project S2009AMB-1668 from the Regional Government of Madrid (Spain). We thank the Regional Forest Service for helping with the plantation.

\section{References}

Adams JC (1997). Mulching improves early growth of four oak species in plantation establishment. Southern Journal of Applied Forestry 21 (1): 44-46. [online] URL: http://www.ingentaconnect.com/content/saf/sjaf/1997/00000021/0 0000001/art00009

Andivia E, Carevic F, Fernández M, Alejano R, Vázquez-Piqué J, Tapias R (2012). Seasonal evolution of water status after outplanting of two provenances of holm oak nursery seedlings. New Forests 43: 815-824. - doi: 10.1007/s11056-0129347-3

Bautista OM, Sparling Y (2009). PARM ICE: Parametric survival models for interval censored data with time-dependent covariates (3.0 edn). Web site. [online] URL: http://www.bsc.gwu.edu Badano E, Pérez D, Vergara CH (2009). Love of nurse plants is not enough for restoring oak forests in a seasonally dry tropical environment. Restoration Ecology 17 (5): 571-576. - doi: 10.1111/j.1526-100X.2009.00530.x

Bellot J, Ortiz de Urbina JM (2008). Soil water content at the catchment level and plant water status relationships in a Mediterranean Quercus ilex forest. Journal of Hydrology 357: 67-75. doi: 10.1016/j.jhydrol.2008.05.002

Calama R, Montero G (2007). Cone and seed production from stone pine (Pinus pinea L.) stands in Central Range (Spain). European Journal of Forest Research 126 (1): 23-35. - doi: 10.1007/ s10342-005-0100-8

Calama R, Puértolas J, Madrigal G, Pardos M (2013a). Modeling the environmental response of leaf net photosynthesis in Pinus pinea L. natural regeneration. Ecological Modelling 251: 921. - doi: 10.1016/j.ecolmodel.2012.11.029

Calama R, Puértolas J, Madrigal G, Manso R, Pardos M (2013b). Modelización fisiológica de la supervivencia del regenerado de $P$. pinea L: efecto de los factores ambientales [Physiological modeling of Pinus pinea seedling survival according to the environmental conditions]. In: Proceedings of the "VI Spanish Forest Congress". Vitoria (Spain) 10-14 June 2013. SECF, Spain, pp. 11. [ISBN: 978-84-937964-9-5]

Ceacero CJ, Díaz-Hernández JL, Del Campo AD, Navarro-Cerrillo RM (2012). Interactions between soil gravel content and neighboring vegetation control management in oak seedling establishment success in Mediterranean environments. Forest Ecology and Management 271: 1018. - doi: 10.1016/j.foreco.2012.01.044

Chaves MM, Pereira JS, Maroco J, Rodrigues ML, Ricardo CPP, Osorio ML, Carvalho I, Faria T, Pinheiro C (2002). How plants cope with water stress in the field. Photosynthesis and growth. Annals of Botany 89: 907-916. - doi: 10.1093/ aob/mcf105

Chirino E, Vilagrosa A, Vallejo VR (2011). Using hydrogel and clay to improve the water status of seedlings for dryland restoration. Plant and Soil 344: 99-110. - doi: 10.1007/s11104-011-0730-1 Cobb WR, Will RE, Daniels RF, Jacobson MA (2008). Aboveground biomass and nitrogen in four short-rotation woody crop species growing with different water and nutrient availabilities. Forest Ecology and Management 255: 4032 4039. - doi: 10.1016/j.foreco.2008.03.045

Costa M, Morla C, Sainz H (1997). Los bosques ibéricos. Una interpretación geobotánica [Iberians forests: a geobotanical interpretation]. Planeta, Barcelona, Spain, pp. 598.

Craven D, Dent D, Braden D, Ashton MS, Berlyn GP, Hall JS (2011). Seasonal variability of photosynthetic characteristics influences growth of eight tropical tree species at two sites with contrasting precipitation in Panama. Forest Ecology and Management 261: 1643-1653 - doi: 10.1016/j.foreco.2010.09.017

Cregg BM, Nzokou PY, Goldy R (2009). Growth and physiology of newly planted fraser fir (Abies fraseri) and Colorado blue spruce (Picea pungens) Christmas trees in response to mulch and irrigation. HortScience 44 (3): 660-665. [online] URL: http://hortsci.ashspublications.org/content/ 44/3/660.short

Dalton CT, Messina MG (1995). Water relations and growth of loblolly pine seedlings planted under a shelterwood and in a clear-cut. Tree Physiology 15: 19-26. - doi: 10.1093/treephys/15.1.19 David TS, Ferreira MI, Cohen S, Pereira JS, David JS (2004). Constraints on transpiration from an evergreen oak tree in southern Portugal. Agricultural and Forest Meteorology 122: 193 205 - doi: 10.1016/j.agrformet.2003.09.014

Filella I, Llusià J. Piñol J, Peñuelas J (1998). Leaf gas exchange and fluorescence of Phillyrea latifolia, Pistacia lentiscus and Quercus ilex saplings in severe drought and high temperature conditions. Environmental and Experimental Botany 39: 213-220 - doi: 10.1016/S0098-8472 (97)00045-2

Fonseca F, de Figueiredo T, Martins A (2011). Survival and early growth of mixed forest stands installed in a Mediterranean region: effects of site preparation intensity. Forest Ecology and Management 262: 1905-1912 - doi: 10.1016/j.foreco.2011.01.040

Galle A, Florez-Sarasa I, El Aououad H, Flexas J (2011). The Mediterranean evergreen Quercus ilex and the semiciduous Cistus albidus differ in their leaf gas exchange regulation and acclimation to repeated drought and re-watering cycles. Journal of Experimental Botany 62(14): 52075216 - doi: $10.1093 / \mathrm{jxb} / \mathrm{err} 233$

Gómez-Aparacio L, Valladares F, Zamora R (2006). Differential light responses of Mediterranean tree saplings: linking ecophysiology with regeneration niche in four co-occurring species. Tree Physiology 26: 947-958. - doi: 10.1093/tree phys/26.7.947

Gordo J, Calama R, Pardos M, Bravo F, Montero $\mathrm{G}$ (2012). La regeneración natural de Pinus 
pinea L. y Pinus pinaster Ait. en los arenales de la Meseta Castellana [Natural regeneration of $P i$ nus pinea L. and Pinus pinaster Ait. in the sandy lands of the Northern Plateau]. IUGFS, Valladolid, Spain, pp. 254.

Gratani L, Bombelli A (2000). Correlation between leaf age and other leaf traits in three Mediterranean maquis shrub species: Quercus ilex, Phillyrea latifolia and Cistus incanus. Environmental and Experimental Botany 43: 141153. - doi: 10.1016/S0098-8472(99)00052-0

Grossnickle SC (2005). Importance of root growth in overcoming planting stress. New Forests 30: 273-294. - doi: 10.1007/s11056-004-8303-2

Grossnickle SC (2012). Why seedlings survive: influence of plant attributes. New Forests 43: 711-738. - doi: 10.1007/s11056-012-9336-6

Guàrdia M, Fernández J, Elena G, Fleck I (2012). Stomatal patchiness in the Mediterranean holm oak (Quercus ilex L.) under water stress in the nursery and in the forest. Tree Physiology 32: 829-838. - doi: 10.1093/treephys/tps035

Gyimah R, Nakao T (2007). Early growth and photosynthetic responses to light in seedlings of three tropical species differing in successional strategies. New Forests 33 (3): 217-236. doi: 10.1007/s1 1056-006-9028-1

Himmelsbach W, Treviño-Garza EJ, GonzálezRodríguez H, González-Tagle MA, Gómez Meza MV, Aguirre Calderón OA, Eduardo Estrada Castillón A, Mitlöhner R (2012). Acclimatation of three co-occurring tree species to water stress and their role as site indicators in mixed pineoak forests in the Sierra Madre Oriental, Mexico. European Journal of Forest Research 131 (2): 355-367. - doi: 10.1007/s10342-011-0507-3

Holmgren M (2000). Combined effects of shade and drought in tulip poplar seedlings: trade-off in tolerance or facilitation? Oikos 90: 67-78. doi: 10.1034/j.1600-0706.2000.900107.x

Hunt R, Causton DR, Shipley B, Askew AP (2002). A modern tool for classical plant growth analysis. Annals of Botany 90: 485-488. - doi: 10.1093/aob/mcf214

Jiménez MN, Fernández-Ondoño E, Ripoll MA, Navarro FB, Gallego E, De Simón E, Lallena AM (2007). Influence of different post-planting treatments on the development in Holm oak afforestation. Trees 21 (4): 443-455. - doi: 10.10 07/s00468-007-0136-0

Kramer DM, Johnson G, Kiirats O, Edwards GE (2004). New fluorescence parameters for the determination of QA redox state and excitation energy fluxes. Photosynthesis Research 79 (2): 209-218. - doi: 10.1023/B:PRES.0000015391. 99477.0d

Kurjak D, Strelcová K, Ditmarová L, Priwitzer T, Kmet' J, Homolák M (2012). Physiological response of irrigated and non-irrigated Norway spruce trees as a consequence of drought in field conditions. European Journal of Forest Research 131: 1737-1746. - doi: 10.1007/s10342-012-06 11-z

Levitt J (1972). Responses of plants to environmental stresses. Academic Press, New York, USA, pp. 698.
Manso R, Pardos M, Keyes C, Calama R (2012). Modelling the spatio-temporal pattern of primary dispersal in Stone pine (Pinus pinea L.) stands in the Northern Plateau (Spain). Ecological Modelling 226: 11-21. - doi: 10.1016/j.ecolmodel.20 11.11 .028

Manso R, Fortin M, Calama R, Pardos M (2013). A novel modelling approach for seed germination in forest tree species. The Pinus pinea L. cases study. Forest Ecology and Management 289: 515-524 - doi: 10.1016/j.foreco.2012.10.0 28

Montero G, Cañadas N, Yagüe S, Calama Sainz R, Garriga R, Bachiller A, Cañellas Rey de Viñas I (2003). Aportaciones al conocimiento de las masas de Pinus pinea L. en los montes de Hoyo de Pinares (Ávila-España) [Contribution to the knowledge of Pinus pinea L. stands in Hoyo de Pinares (Ávila, Spain)]. Montes 73: 30-40. [online] URL: http://dialnet.unirioja.es/servlet/ articulo? codigo $=2027759$

Moreira F, Catry F, Lopes T, Bulgalho MN, Rego F (2009). Comparing survival and size of resprouts and planted trees for post-fire forest restoration in central Portugal. Ecological Engineering 35: 870-873. - doi: 10.1016/j.ecoleng. 2008.12.017

Morison JIL, Jarvis PG (1983). Direct and indirect effects of light on stomata in Scots pine and Sitka spruce. Plant Cell and Environment 6: 95111. - doi: 10.1111/j.1365-3040.1983.tb01881.x Navarro RM, Del Campo A, Cortina J (2006). Factores que afectan al éxito de una repoblación y su relación con la calidad de planta [Factors affecting afforestation success and their relationship with seedling quality]. In: "Calidad de planta forestal para la restauración en ambientes Mediterráneos" (Cortina J, Peñuelas JL, Puértolas J, Savé R, Vilagrosa A eds). M Medio Ambiente, Madrid, Spain, pp. 31-46.

Nikiema P, Nzokou P, Rothstein D (2012). Effects of groundcover management on soil properties, tree physiology, foliar chemistry and growth in a newly established Fraser fir (Abies fraseri [Pursh] Poir) plantation in Michigan, United States of America. New Forests 43. New Forests 43 (2): 213-230. - doi: 10.1007/s11056-011-9274-8 Ogaya R, Peñuelas J (2003a). Comparative field study of Quercus ilex and Phillyrea latifolia: photosynthetic response to experimental drought conditions. Environmental and Experimental Botany 50: 137-148. - doi: 10.1016/S0098-8472 (03)00019-4

Ogaya R, Peñuelas J (2003b). Comparative seasonal gas exchange and chlorophyll fluorescence of two dominant woody species in a holm oak forest. Flora 198: 132-141. - doi: 10.1078/03672530-00085

Ogaya R, Peñuelas J, Asensio D, Llusià J (2011). Chlorophyll fluorescence responses to temperature and water availability in two co-dominant Mediterranean shrub and tree species in a longterm field experiment simulating climate change. Environmental and Experimental Botany 73: 8993. - doi: 10.1016/j.envexpbot.2011.08.004 Pardos M, Puértolas J, Madrigal G, Garriga E, De
Blas S, Calama R (2010). Seasonal changes in the physiological activity of the regeneration under a natural gradient in a Pinus pinea regular stand. Forest Systems 19 (3): 367-380. - doi: 10.5424/fs/2010193-9102

Pausas JG, Bladé C, Valdecantos A, Seva JP, Fuentes D, Alloza JA, Vilagrosa A, Bautista S, Cortina J, Vallejo R (2004). Pines and oaks in the restoration of Mediterranean landscapes of Spain: New perspectives for an old practice - a review. Plant Ecology 171 (1/2): 209-220. - doi: 10.1023/B:VEGE.0000029381.63336.20

Quero JL, Villar R, Marañón T, Zamora R (2006). Interactions of drought and shade effects on seedlings of four Quercus species: physiological and structural leaf responses. New Phytologist 170: 819-834. - doi: 10.1111/j.1469-8137.2006. 01713.x

Rey-Benayas JM (1998). Growth and mortality in Quercus ilex L. seedlings after irrigation and artificial shading on Mediterranean set-aside agricultural lands. Annals of Forest Sciences 55: 801-807. - doi: 10.1051/forest:19980704

Rey-Benayas JM, Camacho-Cruz A (2004). Performance of Quercus ilex saplings planted in abandoned Mediterranean cropland after longterm interruption of their management. Forest Ecology and Management 194: 223-233. - doi: 10.1016/j.foreco.2004.02.035

Rodrigo A, Quintana V, Retana J (2007). Fire reduces Pinus pinea distribution in the northeastern Iberian Peninsula. Ecoscience 14 (1): 23-30. - doi: 10.2980/1195-6860(2007)14[23:FRPPDI] 2.0.CO;2

Rolo V, Plieninger T, Moreno G (2013). Facilitation of holm oak recruitment through two contrasted shrubs species in Mediterranean grazed woodlands. Journal of Vegetation Science 24: 344-355. - doi: 10.1111/j.1654-1103.2012.0145 $8 . \mathrm{x}$

Rosenqvist E, Van Kooten O (2003). Chlorophyll fluorescence: a general description and nomenclature. In: "Practical applications of chlorophyll fluorescence in plant biology" (DeEll JR, Toivonen PMA eds). Kluwer Academic Pub, Boston, Dordrecht, London, pp. 31-37. - doi: 10.10 07/978-1-4615-0415-3 2

Ruiz-Peinado R, Montero G, del Río M (2011). New models for estimating the carbon sink capacity of Spanish softwood species. Forest Systems 20 (1): 176-188. - doi: 10.5424/fs/2011 201-11643

Sack L, Grubb PJ (2002). The combined impacts of deep shade and drought on the growth and biomass allocation of shade-tolerant woody species. Oecologia 131: 171-185. - doi: 10.1007/ s00442-002-0873-0

Schupp EW (1995). Seed-seedling conflicts, habitat choice, and patterns of plant recruitment. American Journal of Botany 82: 399-409. - doi: 10.2307/2445586

Siles G, Rey PJ, Alcántara JM, Bastida JM, Herreros JL (2010). Effects of soil enrichment, watering and seedling age on establishment of Mediterranean woody species. Acta Oecologica 36: 357-364. - doi: 10.1016/j.actao.2010.03.002 
Skroch WA, Powell MA, Bilderback TE, Henry PH (1992). Mulches: durability, aesthetic value, weed control and temperature. Journal of Environmental Horticulture 10 (1): 43-45.

So Y, Johnston G (2010). Analysing interval-censored survival data with SAS software. In: Proceeding of the "SAS Global Forum Conference 2010". Seattle (WA, USA), 11-14 April 2010. SAS Institute Inc., Cary, NC, USA, paper \#257, pp. 1-13.

Soliveres S, Monerris J, Cortina J (2012). Irrigation, organic fertilization and species successional stage modulate the response of woody seedlings to herbaceous competition in a semiarid quarry restoration. Applied Vegetation Science 15: 175-186. - doi: 10.1111/j.1654-109X. 2011.01163.x

Sparling Y, Younes N, Lachin JM, Bautista OM (2006). Parametric survival models for intervalcensored data with time-depedent covariates. Biostatistics 7 (4): 599-614. - doi: 10.1093/biostatistics $/ \mathrm{kxj} 028$

Stephens SC, Millar CI, Collins BM (2010). Operational approaches to managing forests of the future in Mediterranean regions within a contex of changing climates. Environmental Research Letters 5: 1-9. [online] URL: http://iopscience. iop.org/1748-9326/5/2/024003

Sun J, Zhao Q, Zhao X (2005). Generalized logrank test for interval-censored failure time data. Scandinavian Journal of Statistics 32: 49-57. doi: 10.1111/j.1467-9469.2005.00414.x

Valladares FI, Dobarro I, Sánchez-Gómez D, Pearcy RW (2005). Photoinhibition and drought in Mediterranean woody samplings: scaling effects and interactions in sun and shade phenotypes. Journal of Experimental Botany 56: 483494. - doi: 10.1093/jxb/eri037

Vallejo VR, Smanis A, Chirino E, Fuentes D, Valdecantos A, Vilagrosa A (2012). Perspectives in dryland restoration: approaches for climate change adaptation. New Forests 43: 561-579. doi: 10.1007/s11056-012-9325-9

Verbeke G, Molenberghs G (2000). Linear mixed models for longitudinal data. Springer Series in Statistics, Springer-Verlag. New York, pp. 568. Villar-Salvador P, Puértolas J, Cuesta B, Peñuelas JL, Uscola M, Heredia-Guerrero N, Rey Benayas JM (2012). Increase in size and nitrogen concentration enhances seedling survival in Mediter- ranean plantations. Insights from an ecophysiological conceptual model of plant survival. New Forests 43 (5-6): 755-770. - doi: 10.1007/s11056 $-012-9328-6$

Villar-Salvador P, Peñuelas JL, Jacobs DF (2013). Nitrogen nutrition and drought hardening exert opposite effects on the stress tolerance of Pinus pinea L. seedlings. Tree Physiology 33 (2): 221 232. - doi: 10.1093/treephys/tps 133

Wellner JA, Zhan Y (1997). A hybrid algorithm for computation of the nonparametric maximum likelihood estimator for censored data. Journal of the American Statistics Assoiation 92: 945-959. - doi: 10.1080/01621459.1997.10474049

Xu L, Baldocchi DD (2003). Seasonal trends in photosynthetic parameters and stomatal conductance of blue oak (Quercus douglasii) under prolongued summer drought and high temperature. Tree Physiology 23: 865-877. - doi: 10.1093/tree phys/23.13.865

Zhao Q, Sun J (2004). Generalized log-rank test for mixed interval-censored failure time data. Statistics and Medicine 23: 1621-1629. - doi: 10.1002/sim. 1746 